\title{
PENGHAMBATAN PERTUMBUHAN Klebsiela pneumoniae DENGAN EKSTRAK ETANOL DARI LIMBAH KULIT PISANG KEPOK (Musa paradisiaca L.)
}

\author{
Vector Stephen Dewangga ${ }^{1}$, Muhammad Taufiq Qurrohman ${ }^{2}$ \\ Sekolah Tinggi Ilmu Kesehatan Nasional \\ $\boldsymbol{e}$-mail vector.stephen@stikesnas.ac.id
}

\begin{abstract}
ABSTRAK
Pisang kepok (Musa paradisiaca L.) adalah buah yang mudah ditemukan, akan tetapi kulit buahnya selama ini jarang dimanfaatkan. Pada kulit buah M. paradisiaca L. terkandung flavonoid, alkaloid, tanin, saponin, dan terpenoid yang berperan sebagai senyawa antibakteri. Penelitian ini bertujuan untuk mengetahui apakah ekstrak etanol limbah kulit M. paradisiaca L. mampu menghambat pertumbuhan Klebsiella pneumoniae. Metode penelitian yang digunakan adalah analitik eksperimental, sampel kulit M. paradisiaca L. diperoleh dari pedagang keripik pisang kepok di Kabupaten Karanganyar. Ekstrak etanol 96\% kulit M. paradisiaca L. dibuat dengan menggunakan metode perkolasi, sedangkan uji aktivitas antibakteri dilakukan dengan metode Kirby-Bauer. Hasil penelitian menunjukkan bahwa ekstrak etanol 96\% limbah kulit M. paradisiaca L. mampu menghambat pertumbuhan bakteri K. pneumoniae, pada konsentrasi $20 \%$; $40 \%$; $60 \%$; $80 \%$ dan $100 \%$, dengan rata-rata zona hambat berturut-turut $6,10 \mathrm{~mm} ; 6,35 \mathrm{~mm} ; 6,95 \mathrm{~mm} ; 7,35 \mathrm{~mm}$; dan 7,80 mm. Ekstrak etanol $96 \%$ kulit $M$. paradisiaca L. mampu membentuk zona hambat radikal pada semua konsentrasi terhadap pertumbuhan $K$. pneumoniae, namun tidak mampu menghasilkan zona hambat radikal setara dengan kriteria sensitif antibiotik ciprofloxacin $5 \mu \mathrm{g}$ berdasarkan CLSI 2018 terhadap pertumbuhan K. pneumoniae.
\end{abstract}

Kata Kunci: Kulit buah Musa paradisiaca L, ekstrak etanol 96\%, Klebsiella pneumoniae, zona hambat

\begin{abstract}
Banana kepok (Musa paradisiaca L.) is a fruit that is easily found, but the peel of the fruit has rarely been used. The peel of $M$. paradisiaca L. contains flavonoids, alkaloids, tannins, saponins, and terpenoids which act as antibacterial compounds. This study aims to determine whether the ethanol extract of $M$. paradisiaca L. peel can inhibit the growth of Klebsiella pneumoniae. The research method used was an experimental analytic, $M$. paradisiaca L. peel samples were obtained from banana chips traders in Karanganyar. Ethanol extract $96 \%$ of the skin of $M$. paradisiaca $\mathrm{L}$. was prepared using the percolation method, whereas the antibacterial activity test was carried out by the Kirby-Bauer method. The results showed that the $96 \%$ ethanolic extract of $M$. paradisiaca L.peel was able to inhibit the growth of K. pneumoniae in 20\%; $40 \%$; $60 \%$; $80 \%$ and $100 \%$ concentrations, with mean inhibitory zones in order 7,46 mm; 7,52 mm; 7,60 mm; $8,52 \mathrm{~mm}$; dan $8,98 \mathrm{~mm}$. $96 \%$ of ethanolic extract $M$. paradisiaca $\mathrm{L}$. skin was able to form radical inhibitory zones at all concentrations of $\mathrm{K}$. pneumoniae growth, but was unable to produce radical inhibitory zones equivalent to the $5 \mu \mathrm{g}$ ciprofloxacin antibiotic sensitive criteria based on CLSI 2018 on the growth of K. pneumoniae.
\end{abstract}

Keywords:; Peel of Musa paradisiaca L, $96 \%$ of ethanolic extract, Klebsiella pneumoniae, inhibition zone

\section{PENDAHULUAN}

Pneumonia atau infeksi saluran nafas di Indonesia merupakan salah satu penyakit yang paling banyak diderita oleh masyarakat. Berdasarkan hasil penelitian kesehatan dasar Riskesdas 2013, pneumonia menduduki tempat kedua sebagai penyebab kematian pada bayi dan balita (Caesar dkk., 2015). Salah satu bakteri penyebab pneumonia adalah Klebsiella pneumonia (Kartasamita, 2010). Bakteri ini masih menjadi salah satu penyebab utama pneumonia komunitas di beberapa negara
(Tarina dan Kusuma, 2017). Badan penelitian dan Pengembangan Kesehatan RI mendapatkan hasil biakan sputum yaitu Klebsiella pneumoniae sebesar 29\% dan merupakan angka tertinggi dibanding bakteri lain (PDPI, 2014).

Pengobatan pada pasien yang disebabkan infeksi bakteri umumnya menggunakan antibiotik. Kontrol penggunaan antibiotik yang tidak tepat akan menyebabkan resistensi bakteri terhadap antibiotik (Tandari, 2016). Berdasarkan penelitian yang dilakukan Tandari 2016, Klebsiella pneumoniae telah resisten terhadap 
obat antibiotik amoxicilin, sulfamethoxazole, seftriakson, seftazidim dan amplisiklin sebesar $100 \%$.

Obat alternatif yang dapat digunakan untuk pengobatan infeksi bakteri adalah obat herbal. Salah satu contoh obat herbal yaitu kulit pisang kepok (Musa paradisiaca L.). Kulit $M$. paradisiaca $\mathrm{L}$. mengandung senyawa flavonoid, alkaloid, tanin, saponin, dan terpenoid yang berperan sebagai senyawa antibakteri (Oktavianto, 2018).

\section{METODE PENELITIAN}

Metode penelitian yang digunakan adalah analitik eksperimental. Sampel kulit $M$. paradisiaca L. diperoleh dari pedagang keripik pisang kepok di Kabupaten Karanganyar, ekstrak etanol $96 \%$ kulit $M$. paradisiaca L dibuat dengan menggunakan metode perkolasi dan dilaksanakan di Laboratorium Obat Tradisional STIKES Nasional Surakarta. Tempat uji aktivitas antibakteri ekstrak dan pembuatan konsentrasi ekstrak etanol $96 \%$ kulit $M$. paradisiaca L. di Laboratorium Bakteriologi STIKES Nasional. Waktu untuk penelitian dilaksanakan pada bulan April hingga Mei 2019. Penelitian menggunakan metode difusi disk.

Teknik sampling yang digunakan adalah quota sampling. Konsentrasi ekstrak etanol 96\% kulit $M$. paradisiaca L yang digunakan adalah $20 \%, 40 \%, 60 \%, 80 \%$ dan $100 \%$.

a. Alat dan Bahan

Alat yang digunakan adalah ohse bulat, ohse lurus, pembakar spiritus, inkubator, mikroskop, timbangan analitik, dan autoclave. Bahan yang digunakan yaitu kulit M. paradisiaca L., etanol 96\%, perkolator, suspensi Klebsiella pneumoniae, cat Gram A, cat Gram B, cat Gram C, cat Gram D, media MC (Mac Conkey), media MHA (Mueller Hinton Agar), media BHI (Brain Heart Infusion), blank disk, tip, mikropipet media uji biokimia, reagen Kovac, Barried, $\mathrm{KOH}$ $40 \%, \mathrm{FeCl}_{3}$ 10\%, Methyl Red, $\mathrm{NaCl} 0.9 \%$, minyak emersi, alkohol mikroskop, standar Mc Farland 0,5, ciprofloxacin $5 \mu \mathrm{g}$, DMSO (dimethyl sulfoxide) 10\%, dan aquadest steril.

b. Persiapan sampel

Menggunakan kulit pisang dengan kriteria kulit pisang kepok yang berwarna hijau tua. Kulit $M$. paradisiaca L. yang akan dilakukan ekstraksi ,kulit dicuci terlebih dahulu menggunakan air mengalir hingga bersih, ditiriskan dan di potong kecil- kecil. Kemudian kulit $M$. paradisiaca L. dikeringkan di bawah sinar matahari dengan ditutup kain hitam hingga kering, tanda kulit M. paradisiaca L. dapat dipatahkan seperti kayu (Utomo dkk., 2009).

c. Prosedur Perkolasi

Perkolasi dilakukan dengan prosedur menimbang 200 gram simplisia halus lalu dilakukan semi maserasi terlebih dahulu menggunakan beaker glass dengan diberi penyari etanol $96 \%$ sebanyak $200 \mathrm{ml}$ rendam selama 1-2 jam. Proses selanjutnya memasukan simplisia tadi kedalam perkolator yang telah dipasang pada satisnya lalu masukan simplisia yang telah disemi maserasi lalu tuang etanol $96 \%$ hingga tanda $800 \mathrm{ml}$ pada perkolator dan tutup dengan plastik tunggu hingga 24 jam.

Setelah 24 jam bula keran perkolator dan alirkan hasil filtrat dengan kecepatan $1 \mathrm{ml} /$ menit hingga larutan penyari turun sampai $400 \mathrm{ml}$, setelah itu tampung pada beaker glass dan tuang kembali etanol $96 \%$ hingga tanda $800 \mathrm{ml}$ dan lalukan selama 3 hari.

Filtrat dimasukan kedalam rotary evaporator untuk dipekatkan dengan suhu $45^{\circ} \mathrm{C}$ sampai diperoleh ekstrak kental kulit M. paradisiaca $\mathrm{L}$. hasil kemudian dituang dalam wadah botol steril dan disimpan dalam lemari pendingin (Padmasari, 2013).

d. Uji flavonoid (Rumagit dkk., 2015)

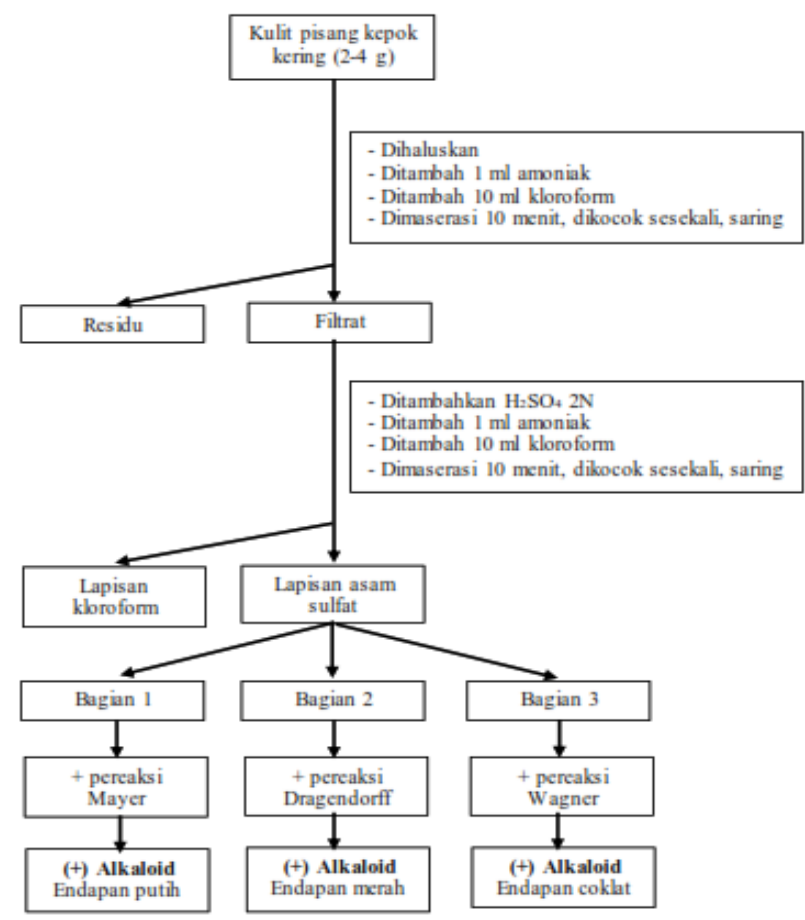

Gambar 1. Bagan Uji Flavonoid 
e. Uji alkaloid

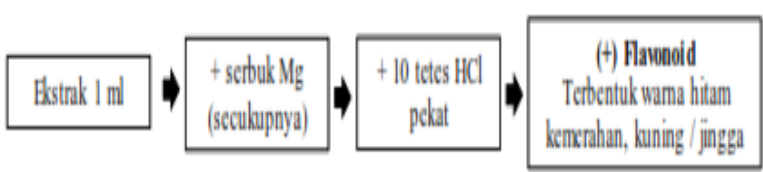

Gambar 2. Bagan Uji Alkaloid (Rizky dan Suyatno, 2014)

f. Uji tannin

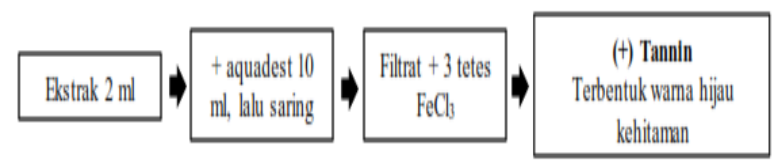

Gambar 3. Bagan Uji Tannin (Apriyuslim, 2015)

g. Uji saponin

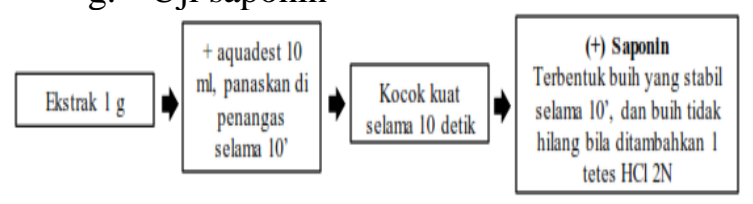

Gambar 4. Bagan Uji Saponin (Hanani, 2015)

h. Uji terpenoid

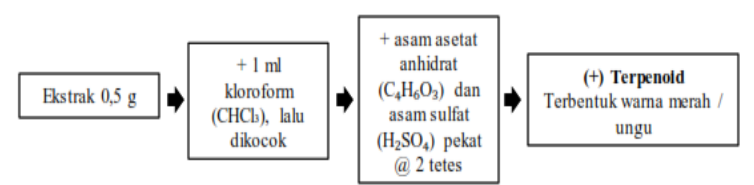

Gambar 5. Bagan Uji Terpenoid (Pangow dkk., 2018)

i. Pembuatan konsentrasi ekstrak. Konsentrasi ekstrak $100 \%$ timbang 2 gram larutkan dalam $2 \mathrm{ml}$ DMSO 10\%. Konsentrasi 80\% dengan cara pipet 1,6 ml konsentrasi $100 \%$ ditambah $0,4 \mathrm{ml}$ DMSO $10 \%$. Konsentrasi $60 \%$ pipet $1,2 \mathrm{ml}$ konsentrasi $100 \%$ ditambah $0,8 \mathrm{ml}$ DMSO $10 \%$. Konsentrasi $40 \%$ pipet $0,8 \mathrm{ml}$ konsentrasi $100 \%$ ditambah $0,2 \mathrm{ml}$ DMSO $10 \%$. Konsentrasi $20 \%$ pipet $0,4 \mathrm{ml}$ konsentrasi $100 \%$ ditambah 1,6 ml DMSO 10\% (Narulita, 2017).

j. Pembuatan kontrol negatif (DMSO 10\%). Ukur $10 \mathrm{ml}$ DMSO 100\% tambahkan $90 \mathrm{ml}$ aquades steril, lalu homogenkan (Assidqi dkk., 2014).

k. Pembuatan kontrol positif (ciprofloxacin 5 $\mu \mathrm{g})$ menggunakan disk antibiotik ciprofloxacin $5 \mu \mathrm{g}$

1. Pembuatan suspensi inokulum Klebsiella pneumoniae. Klebsiella pneumoniae dari media NA miring diambil dengan ohse steri, kemudian menambahkan larutan $\mathrm{NaCl}$ 0,9\% di dalam tabung sampai didapatkan kekeruhan yang sesuai dengan standar kekeruhan McFarland 0.5 untuk mendapatkan bakteri sebanyak $1,5 \times 10^{8}$ CFU/ml (Salim, 2016).

m. Prosedur uji antimikroba metode difusi disk. Celupkan kapas lidi steril ke dalam sampel yang sudah dibandingkan kekeruhannya dengan standar Mc Farland no 0,5 secara aseptis. Kemudian di ratakan pada media MHA plate secara aseptis. Inkubasi selama 15 menit pada suhu $37^{\circ} \mathrm{C}$. Kemudian letakan blank disk di atas media MHA plate dengan jarak yang tidak terlalu dekat. Ambil $20 \mu \mathrm{l}$ dari masing-masing variasi konsentrasi larutan uji $(20 \%, 40 \%, 60 \%, 80 \%, 100 \%)$ dan larutan DMSO 10\% sebagai kontrol negatif untuk dimasukan ke dalam blank disk steril yang berdiameter $6 \mathrm{~mm}$. untuk kontrol positif menggunakan disk antibiotik ciprofloxacin $5 \mu \mathrm{g}$. Inkubasi pada suhu $37^{\circ} \mathrm{C}$ selama 24 jam (Fitriani, 2014).

n. Analisa data

Teknik analisis pada penelitian ini ditentukan berdasarkan hasil pengamatan terbentuknya zona hambat radikal pada media Mueller Hinton Agar di semua variasi konsentrasi ekstrak etanol $96 \%$ kulit $M$. paradisiaca L. Data hasil uji daya hambat dari masingmasing konsentrasi ekstrak etanol $96 \%$ kulit $M$. paradisiaca $\mathrm{L}$. terhadap pertumbuhan Klebsiella pneumoniae selanjutnya diratarata dan dianalisis dengan menggunakan Anova di SPSS 19 sehingga diperoleh data signifikansi variasi konsentrasi serta kaitan variasi konsentrasi sensitivitas dengan kontrol positif ciprofloxacin 5 ug berdasarkan CLSI 2018.

\section{HASIL DAN PEMBAHASAN}

a. Uji fitokimia ekstrak etanol $96 \%$ kulit $M$. paradisiaca $\mathrm{L}$.

Hasil uji fitokimia menunjukkan bahwa kulit $M$. paradisiaca $\mathrm{L}$. positif mengandung flavonoid, alkaloid, tannin, saponin dan terpenoid (Tabel 1). Berdasarkan Tabel 2, kontrol positif ciprofloxacin $5 \mu \mathrm{g}$ mampu membentuk zona hambat radikal dengan rata- rata $21,59 \mathrm{~mm}$ dan kontrol negatif DMSO 10\% tidak mampu membentuk zona hambat radikal karena pada dasarnya tidak memiliki sifat antibakteri. Pada konsentrasi ekstrak etanol 96\% kulit $\mathrm{M}$. paradisiaca $\mathrm{L}$. terbentuk zona hambat radikal pada konsentrasi 20\%, 40\%, 60\%, 80\% dan 
$100 \%$ dengan nilai secara berurutan sebesar 6,$10 ; 6,35 ; 6,95 ; 7,35$ dan 7,80. yang berarti semua variasi konsentrasi ekstrak kulit $M$. paradisiaca $\mathrm{L}$. mampu membentuk zona hambat radikal terhadap pertumbuhan $K$. pneumoniae. Data hasil perhitungan rata-rata zona hambat radikal yang terbentuk, lalu dianalisis dengan Anova yang dilanjutkan dengan Post Hoc Test menggunakan program SPSS 19, sehingga diperoleh nilai signifikansi penelitian dan perbedaan nilai variasi konsentrasi ekstrak etanol 96\% kulit $M$. paradisiaca L. terhadap pertumbuhan Klebsiella pneumoniae.

Tabel 1. Hasil Uji Fitokimia Ekstrak Kulit Musa paradisiaca $\mathrm{L}$.

\begin{tabular}{|c|c|c|c|}
\hline No & Senyawa aktif & Hasil & Keterangan \\
\hline 1 & Flavanoid & + & $\begin{array}{l}\text { Terbentuk warna } \\
\text { kemerahan }\end{array}$ \\
\hline \multirow[t]{4}{*}{2} & Alkaloid & & \\
\hline & a. Mayer & + & $\begin{array}{l}\text { Terbentuk endapan } \\
\text { putih kekuningan }\end{array}$ \\
\hline & b. Wagner & + & $\begin{array}{l}\text { Terbentuk endapan } \\
\text { coklat }\end{array}$ \\
\hline & c. Dragendorff & + & $\begin{array}{l}\text { Terbentuk endapan } \\
\text { jingga }\end{array}$ \\
\hline 3 & Tannin & + & $\begin{array}{l}\text { Terbentuk warna } \\
\text { hijau kehitaman }\end{array}$ \\
\hline 4 & Saponin & + & $\begin{array}{l}\text { Terbentuk busa } \\
\text { stabil dalam } 10 \\
\text { menit dengan } \\
\text { penembahan } \mathrm{HCl} \\
\text { 2N sebanyak } 1 \text { tetes }\end{array}$ \\
\hline 5 & Terpenoid & + & $\begin{array}{l}\text { Terbentuk warna } \\
\text { merah keunguan }\end{array}$ \\
\hline
\end{tabular}

b. Hasil uji aktivitas ekstrak etanol $96 \%$ dari kulit M. paradisiaca $\mathrm{L}$.

Tabel 2. Zona hambat radikal Uji Daya Hambat Ekstrak Kulit Musa paradisiaca L. Terhadap Pertumbuhan Klebsiella

pneumoniae

\begin{tabular}{cccccccc}
\hline \multicolumn{7}{c}{$\begin{array}{c}\text { KONSENTRASI EKSTRAK } \\
\text { Zona Radikal (mm) }\end{array}$} \\
\hline Ulangan & $\begin{array}{c}\text { Kontrol } \\
(-)\end{array}$ & $\mathbf{2 0 \%}$ & $\mathbf{4 0 \%}$ & $\mathbf{6 0 \%}$ & $\mathbf{8 0 \%}$ & $\mathbf{1 0 0 \%}$ & $\begin{array}{c}\text { Kontrol } \\
(+)\end{array}$ \\
\hline I & $\mathbf{6 . 0 0}$ & $\mathbf{6 . 1 0}$ & $\mathbf{6 . 2 0}$ & $\mathbf{7 . 2 0}$ & $\mathbf{7 . 4 5}$ & $\mathbf{8 . 5 0}$ & $\mathbf{2 1 . 5 5}$ \\
II & $\mathbf{6 . 0 0}$ & $\mathbf{6 . 2 5}$ & $\mathbf{6 . 9 5}$ & $\mathbf{7 . 1 5}$ & $\mathbf{7 . 3 5}$ & $\mathbf{7 . 7 0}$ & $\mathbf{2 1 . 7 0}$ \\
III & 6.00 & $\mathbf{6 . 0 5}$ & $\mathbf{6 . 2 0}$ & 7.05 & 7.55 & 7.60 & $\mathbf{2 1 . 7 0}$ \\
IV & $\mathbf{6 . 0 0}$ & $\mathbf{6 . 0 0}$ & $\mathbf{6 . 1 5}$ & $\mathbf{6 . 4 0}$ & $\mathbf{7 . 0 5}$ & $\mathbf{7 . 2 0}$ & $\mathbf{2 1 . 4 0}$ \\
\hline Rata- & $\mathbf{6 . 0 0}$ & $\mathbf{6 . 1 0}$ & $\mathbf{6 . 3 5}$ & $\mathbf{6 . 9 5}$ & $\mathbf{7 . 3 5}$ & $\mathbf{7 . 8 0}$ & $\mathbf{2 1 . 5 9}$ \\
Rata & & & & & & & \\
\hline
\end{tabular}

Ket: zona hambat radikal termasuk diameter disk (6 mm)
Tabel 3. Hasil Uji ANOVA

\begin{tabular}{crrrrr}
\multicolumn{5}{c}{ ANOVA } \\
Perlakuan \\
\hline & $\begin{array}{c}\text { Sum of } \\
\text { Squares }\end{array}$ & \multicolumn{4}{c}{ Mean } \\
df & Square & F & Sig. \\
\hline Between & 764,483 & 6 & 127,414 & 1348,380 &, 000 \\
Groups & & & & & \\
Within & 1,984 & 21 &, 094 & & \\
Groups & & & & & \\
Total & 766,467 & 27 & & \\
\hline
\end{tabular}

Dari Tabel 3. diperoleh hasil bahwa nilai signifikansi $\mathrm{p}<0,05$, yang artinya $\mathrm{H}_{0}$ ditolak sedangkan $\mathrm{H}_{1}$ diterima, yang artinya variasi konsentrasi ekstrak etanol $96 \%$ kulit $M$. paradisiaca L. mampu menghambat pertumbuhan $K$. pneumoniae secara signifikan.

Tabel 4. Hasil Uji Post-Hoc Daya Hambat Ekstrak Etanol Kulit Musa paradisiaca L. Terhadap Pertumbuhan Escherichia coli

\begin{tabular}{cc}
\hline Konsentrasi & $\begin{array}{c}\text { Rata-rata Diameter } \\
\text { Zona Hambat }(\mathrm{mm})\end{array}$ \\
\hline Kontrol (-) & $6^{\mathrm{a}}$ \\
$20 \%$ & $6,1^{\mathrm{a}}$ \\
$40 \%$ & $6,35^{\mathrm{a}}$ \\
$60 \%$ & $6,95^{\mathrm{b}}$ \\
$80 \%$ & $7,35^{\mathrm{bc}}$ \\
$100 \%$ & $7,80^{\mathrm{c}}$ \\
Kontrol (+) & $21,5875^{\mathrm{d}}$ \\
\hline
\end{tabular}

Keterangan: Huruf yang berbeda di belakang angka menunjukkan beda signifikan berdasarkan uji post-hoc metode DMRT dengan $\mathrm{p}<0,05$

Dari Tabel 4. dapat diketahui bahwa konsentrasi $100 \%$ ekstrak kulit $M$. paradisiaca L. tidak mampu membentuk zona hambat radikal yang setara dengan antibiotik ciprofoxacin 5 $\mu \mathrm{g}$ menurut CLSI 2018 dalam menghambat Klebsiella penumoniae. Zona hambat radikal yaitu suatu daerah di sekitar disk yang sama sekali tidak ditemukan adanya pertumbuhan bakteri (Sulistyowati dan Agnes, 2011).

Kontrol negatif yang digunakan adalah DMSO $10 \%$ yang merupakan salah satu pelarut yang dapat melarutkan hampir semua senyawa baik polar maupun non polar (Fadila dkk., 2015). Selain itu DMSO tidak bersifat bakterisidal sehingga tidak memberikan daya hambat terhadap pertumbuhan $K$. pneumoniae sehingga tidak mengganggu hasil pengamatan (Assidiqi dkk., 2012). Kontrol positif yang digunakan yaitu antibiotik ciprofloxacin $5 \mu \mathrm{g}$ yangmembentuk zona hambat radikal dengan besar rata- rata $21,59 \mathrm{~mm}$. Menurut CLSI (2018) ciprofloxacin $5 \mu \mathrm{g}$ dikatakan sensitif apabila memiliki zona hambat radikal yang terbentuk $\geq 21 \mathrm{~mm}$, intermediet apabila terbentuk zona hambat radikal 
dengan ukuran 16- $20 \mathrm{~mm}$ dan dikatakan resisten apabila terbentuk zona hambat radikal dengan ukuran $\leq 15 \mathrm{~mm}$, dengan demikian Klebsiella pneumoniae sensitif terhadap ciprofloxacin $5 \mu \mathrm{g}$.

Ciprofloxacin merupakan obat antibiotik golongan fluorokinolon (Alfarizi, 2017). Antibiotik ciprofloxacin memiliki mekanisme menghambat enzim topoisomerase tipe II, yaitu DNA grainase dan topoisomerase IV, kedua enzim terlibat dalam replikasi DNA bakteri, enzim grainase mengganggu kerenggangan superkoil positif dari DNA bakteri sedangkan topoisomerase IV akan mengagalkan ikatan DNA sehingga tidak dapat bereplikasi. Akibatnya terbentuk ikatan kompleks antibiotik golongan fluorokuinolon bersama DNA grainase dan kompleks fluorokinolon brsama DNA topoisomerase IV, meyebabkan terhambatnya replikasi bakteri sehingga terjadi kematian sel (Rachmad, 2017).

Zona hambat radikal yang terbentuk pada uji aktivitas ekstrak kulit M. paradisiaca L. terhadap pertumbuhan Klebsiella pneumoniae karena adanya kandungan senyawa antibakteri dalam kulit $\mathrm{M}$. paradisiaca L. Dari Tabel 1. diperoleh hasil positif uji fitokimia kulit M. paradisiaca L. berupa senyawa flavanoid, alkaloid, tanin, saponin dan terpenoid yang setiap senyawa memiliki aktivitas antibakteri. Flavonoid mendenaturasi protein sel bakteri dan merusak membran sel bakteri (Afiff dan Amilah, 2017). Alkaloid mengganggu komponen penyusun peptidoglikan sel bakteri, sehingga lapisan dinding sel tidak terbentuk sempurna dan menyebabkan kematian sel (Hasibuan, 2016). Tanin memunculkan denaturasi protein dan menurunkan teganggan permukaan, sehingga permeabilitas bakteri meningkat (Azizah, 2016). Saponin dapat menghambat sintesis protein sehingga menyebabkan kerusakan komponen-komponen penyusun sel bakteri (Hasibuan, 2016). Terpenoid menembus dinding sel bakteri lalu merusak porin sehingga bakteri mengalami kekurangan zat nutrisi sehingga menghambat pertumbuhannya (Hasibuan, 2016).

Pada penelitian ini didapatkan hasil semua konsentrasi kulit M. paradisiaca L. membentuk zona hambat radikal terhadap pertumbuhan Klebsiella pneumoniae. Perbedaan luas zona hambat radikal dipengaruhi oleh Semakin pekat konsentrasi suatu ekstrak yang digunakan maka senyawa metabolit sekunder yang berada di dalamnya akan semakin banyak jumlahnya sehingga berpengaruh terhadap luas diameter zona hambat radikal yang terbentuk (Putri dkk., 2017). Menurut Yunikawati (2013), bahwa zat fitokimia dalam bahan herbal lebih potensial menghambat bakteri gram positif dari pada bakteri gram negatif karena bakteri gram positif memiliki lapisan fosfolipid yang lebih tipis dan bersifat polar sehingga ekstrak lebih mudah menembus dinding sel. Tetapi pada bakteri gram negatif yang memiliki lapisan fosfolipid yang tebal namun masih mampu dihambat oleh ekstrak kulit $\mathrm{M}$. paradisiaca L. zona radikal yang terbentuk pada konsentrasi $100 \%$ tidak setara antibiotik ciprofloxacin $5 \mu \mathrm{g}$ dikarenakan bahan herbal yang mengandung senyawa fitokimia (flavanoid, alkaloid, tanin, saponin dan terpenoid) hanya memiliki mekanisme merusak membran sel dan protein sel bakteri sedangkan antibiotik ciprofloxacin merusak hingga replikasi DNA bakteri.

Beberapa faktor yang mempengaruhi kualitas ekstrak antara lain faktor kimia seperti jenis dan jumlah senyawa kimia, metode untuk ekstraksi serta pelarut yang digunakan. Aktivitas antibakteri dalam menghambat pertumbuhan bakteri juga di pengaruhi oleh konsentrasi senyawa aktif yang tersaring pada masing-masing konsentrasi. Dengan adanya penambahan konsentrasi maka kandungan senyawa antibakteri akan semakin besar pula sehingga semakin banyak pula senyawa antibakteri yang berdifusi ke dalam sel (Nuria dkk., 2015).

\section{KESIMPULAN}

Hasil penelitian yang telah dilakukan, diperoleh simpulan ekstrak etanol 96\% kulit M. paradisiaca L. mampu membentuk zona hambat radikal pada semua konsentrasi terhadap pertumbuhan Klebsiella pneumoniae. Hasil penelitian yang telah dilakukan, diperoleh simpulan ekstrak etanol 96\% kulit $M$. paradisiaca $\mathrm{L}$. tidak mampu menghasilkan zona hambat radikal setara dengan kriteria sensitif antibiotik ciprofloxacin $5 \mu \mathrm{g}$ berdasarkan CLSI 2018 terhadap pertumbuhan Klebsiella pneumoniae

\section{Saran}

Bagi peneliti selanjutnya:

a. Perlu memperhatikan proses pembuatan suspensi dan menyetarakan dengan standar Mc Farland 0,5.

b. Perlu melakukan uji aktivitas antibakteri ekstrak etanol $96 \%$ kulit $M$. paradisiaca L. terhadap bakteri lain misalnya Acinetobacter baumannii, Proteus vulgaris, Mycobacterium tuberculosis, Streptococcus pneumoniae dan lain-lain.

c. Perlu menggunakan variasi konsentrasi yang lain dengan satuan ppm.

d. Menggunakan senyawa fitokimia secara tunggal misalnya hanya mengambil senyawa tanin nya saja untuk uji antibakteri.

e. Perlu melakukan uji kadar senyawa fitokimia ekstrak kulit $M$. paradisiaca L. secara kuantitatif.

f. Perlu mencoba pelarut lain, sebagai contoh: metanol, n-heksan, kloroform dan lain- lain. 
g. Perlu mencoba ekstraksi dengan sokhletasi, destilasi dan lain- lain.

\section{REFERENSI}

Affif, F, E. dan Amilah, S. (2017). Efektivitas Ekstrak Daun Mengkudu (Morinda citrifolia L.) dan Daun Sirih Merah (Piper crocatum R \& P) Terhadap Zona Hambat Pertumbuhan Staphylococcus aureus. Journal of Science. 3(1) : 21-30

Alfarizi, M, E. (2015). Pola Mikroorganisme Penyebab Penyakit Pneumoniae Dan Sensitivitsnya Terhadap Antibiotik Di Masyarakat Bandar Lampung. Skripsi. Universitas Bandar Lampung

Apriyuslim, R, P. (2015). Uji Aktivitas Antibakteri Ekstrak Etanol Daun Sirsak (Annona muricata L.) Terhadap Salmonella typhi Secara In Vitro. Naskah Publikasi. Universitas Tanjungpura.

Assidqi, K., Wahyu, T. dan Setyawati, S. (2012). Potensi Ekstrak Daun Patikan Kebo (Euphorbia hirta) Sebagai Antibakteri Terhadap Aeromonas hydrophila Secara In Vitro. Journal Of Marine and Coastal Science. 1 (2):113-124

Azizah, N, G. (2016). Analisis Ekstrak Batang dan Akar Pisang Kepok (Musa paradisiaca L.) Dalam Menghambat Pertumbuhan Candida albicans. Skripsi. Universitas Hasanuddin Makasar.

Caesar, D, L,.Nurjazuli, W dan Nur Endah. (2015). Hubungan Jumlah Bakteri Patogen Dalam Rumah Dengan Kejadian Pneumonia Pada Balita Di Wilayah Kerja Puskesmas Ngesrep Banyumanik Semarang Tahun 2014. Jurnal Kesehatan Lingkungan. 14 (1) : 21-27

CLSI (Clinical and Laboratory Standards Institute). (2018). Performance Standards For Antimicrobial Susceptibility Testing. USA: Twenty-Sevenft Informational Supplement.

Fadlila, W, N., Kiki, M, Y dan Livia, S. (2015). Identifikasi Senyawa Aktif Antibakteri Dengan Metode Bioautografi Kit Terhadap Ekstrak Etanol Tangkai Daun Talas (Colocasia esculenta (L.) Schott). Prosiding Penelitian Spesia Unisba. Hal 583-591.

Fitriani, E. (2017). Uji Aktivitas Antibakteri Ekstrak Etanol Daun Sirsak (Annona Muricata L.) Terhadap Shigella flexneri Secara In Vitro. Naskah publikasi. Universitas Tanjungpura Pontianak.

Hanani, E. (2015). Analisis Fitokimia. Jakarta: Penerbit Buku Kedokteran EGC.
Hasibuan, S. A. (2016). Perbandingan Daya Hambat Ekstrak Daun Jarak Pagar (Jatropha curcas Linn.) Terhadap Pertumbuhan Bakteri Staphylococcus aureus dan Escherichia coli Secara In Vitro. Skripsi. Universitas Lampung.

Kartasasmita, C. B. (2010). Pneumonia Pembunuh Balita. Buletin Jendela Epidemiologi 3: 22-26

Nuria, M. C., Arvin, F., Sumantri. (2009). Uji Aktivitas Antibakteri Ekstrak Etanol Daun Jarak Pagar (Jatropha curcas L.) Terhadap Bakteri Staphylococcus aureus ATCC 25923, Escherichia coli ATCC 25922, dan Salmonella typhi ATCC 1408. Mediagro. 5(2) : 26-37

Oktafianto, D. (2018). Uji Aktivitas Antioksidan dan Tabir Surya Kombinasi Ekstrak Kulit Buah Semangka (Citrullus lanatus) dan Ekstrak Kulit Pisang Kepok (Musa paradisiaca L.). Karya Tulis Ilmiah. STIKES Nasional.

Padmasari, P.D., Astuti, K.W. dan Warditiani, N.K. (2013). Skrining Fitokimia Ekstrak Etanol 70\% Rimpang Bangle (Zingiber purpureum Roxb.). Jurnal Farmasi Udayana. 2(4) :1-7.

Pangow, M, E., Bodhi, W dan Quelijoe, E, D. (2018). Skrining Fitokimia Dan Uji Toksisitas Dari Ekstrak Etanol Daun Manggis (Garcinia mangostana L.) Dengan Metode Brine Shrimp Lethality Test (BSLT). Jurnal Ilmiah Farmasi. 7(3) : 97-107.

PDPI (Perhimpunan Dokter Paru Indonesia). (2014). Pneumonia Komunitas Pedoman Diagnosis dan Penatalaksanaan. Jakarta: Perhimpunan Dokter Paru Indonesia.

Putri, R, W, A. (2016). Identifikasi Bakteri Eschericia coli dan Salmonella sp. Pada Jajanan Batagor Di Sekolah Dasar Negeri di Kelurahan Pisangan, Cirendu, dan Cempaka Putih Kecamatan Ciputat Timur. Skripsi. UIN Syarif Hidayatullah Jakarta.

Rachamd, B. (2017). Isolasi Dan Identifikasi Gen Resisten Ciprofloxacin Pada Isolat Escherichia coli Multridrug Resistance Dari Penderita Infeksi Saluran Kemih Di Rsud Abdoel Moeloek Provinsi Lampung. Tesis. Universitas Islam Lampung.

Rizky, T, A dan Suyatno. (2014). Aktivitas dan Antikanker Ekstrak Metanol Tumbuhan Paku Adiantum philippensis. Unesha Journal of Chemistry. 3 (1) : 89- 98.

Rumangit, H, M., Max, R.J, Runtuwene dan Sudewi,S. (2015). Uji Fitokimia dan Uji Aktivitas Antioksidan Dari Ekstrak Etanol Spons 
Lamellodysidea herbacea. Jurnal Ilmiah Farmasi. 4(3): 183-193

Sulistiyowati Y. dan Agnes, S. S. (2011). Uji Potensi Antibakteri Sodium Ascorbyl Phosphate Terhadap Propionibacterium acnes In Vitro. Mutiara Medika 11(1):8-13.

Tandari, A, D. (2016). Pola Resistensi Bakteri Terhadap Antibiotik Pada Penderita Infeksi Saluran Kemih (ISK) Di Rumah Sakit X Periode Januari 2013September 2015. Publikasi Ilmiah. Universitas Muhammadiyah Surakarta.

Tarina, N, T, I dan Kusuma, A, S. (2017). Deteksi. Bakteri Klebsiella pneumoniae. Farmaka.15 (2) : 119126.

Utomo, A, D., Rahayu,W,R dan Dhiani, B, A. (2009). Pengaruh Beberapa Metode Pengeringan Terhadap Kadar Flavonoid Total Herba Sambiloto ( Andrographis paniculata). Jurnal Pharmacy. 6 (1): 58-70.

Yunikawati, M, P,A., Besung, I, N, K dan Mahatmi, H. (2013). Efektifitas Perasan Daun Srikaya Terhadap Daya Hambat Pertumbuhan Escherichia coli. Indonesia Medicus Veterinus. 2 (2): $170-179$ 